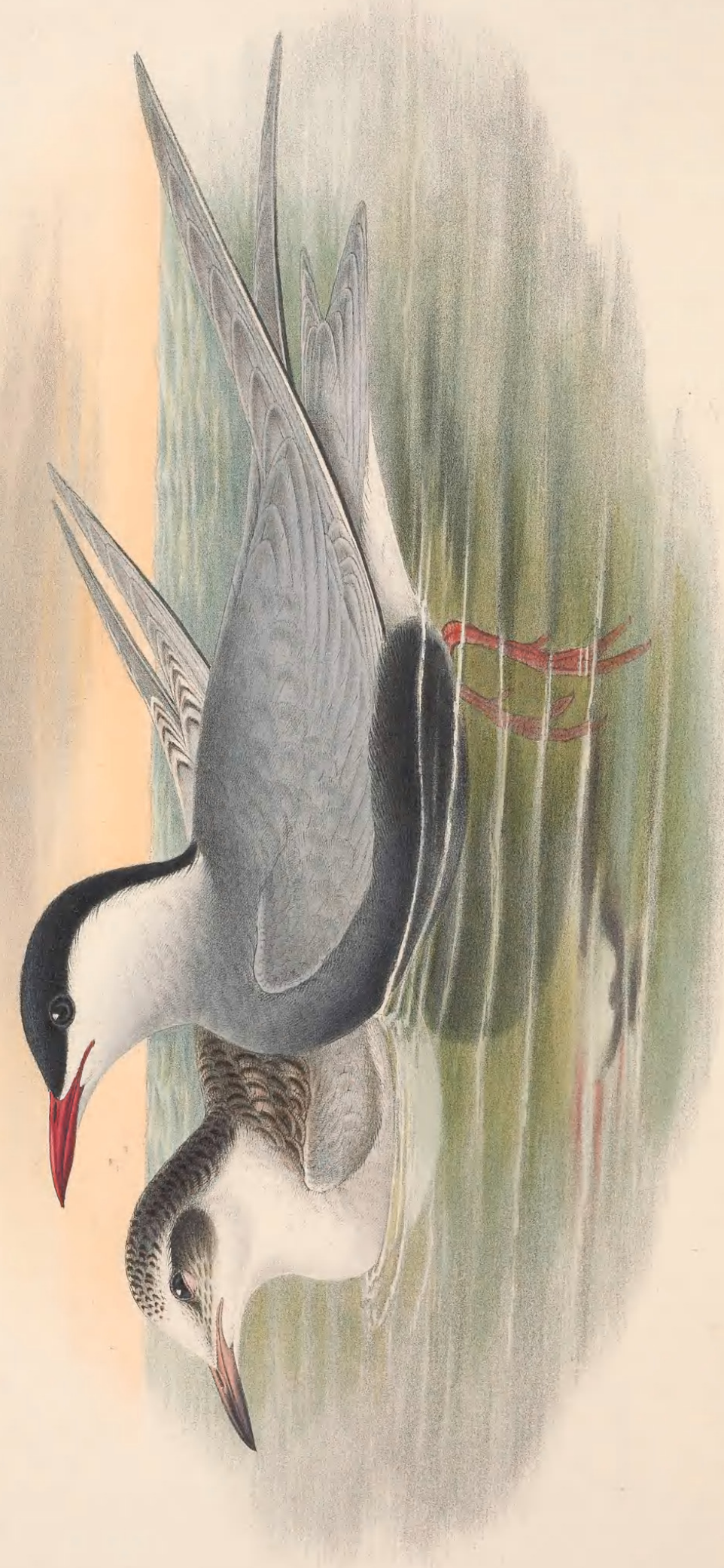

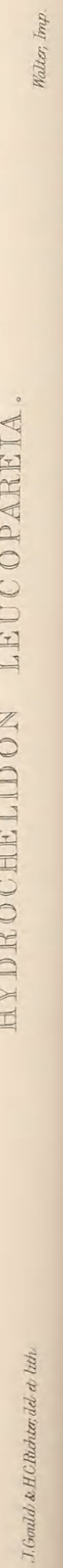




\section{HYDROCHELIDON LEUCOPAREIA.}

\section{Whiskered Tern.}

Sterna hybrida, Pall. Zoog. Ross.-Asiat., tom. ii. p. 338.

leucopareia, Natt., Temm. Man. d'Orn., 1820, tom. ii. p. 746.

Delamotta, Vieill. Ency. Méth. Orn., part i. p. 350.

Viralva indica, Steph. Cont. of Shaw's Gen. Zool., vol. xiii. p. 171.

leucopareia, Steph. ibid., vol. xiii. p. 169.

Pelodes leucopareia, Kaup, Natiirl. Syst., p. 107.

Hydrochelidon leucopareia, Boie.

hybrida, G. R. Gray, Gen. of Birds, vol. iii. p. 660, Hydrochelidon, sp. 1.

Wнy Pallas should have named this well-defined species hybrida I am at a loss to imagine; I must therefore dissent from those of my contemporaries who persist in perpetuating, on the score of priority, such a misnomer; surely the laws of nomenclature are not so rigid as to demand that an appellation so singularly inappropriate shall not give place to the better one of leacopareia, applied to the bird by the late John Natterer, and which, like my friend Schlegel and some other scientific writers, I adopt. It is true that the bird possesses certain characters which would seem to unite Hydrochelidon to Sterna; but these relate to colour rather than to structure; a moment's glance at its feet will show its true position; and on investigation it will be found that its entire actions and economy assimilate to those of the Marsh- rather than to those of the Sea-Terns.

The characters by which it is most nearly allied to the members of the genus Sterna are the possession of a black cap in summer, a portion of which disappears in winter, and the whiteness of the face; the under surface is suffused with bluish black during the summer months, a style of colouring common to all the Marsh-Terns; these peculiarities in its colouring are of much interest as proving the Whiskered Tern to be distinct from both Hydrochelidon nigra and H. leucoptera.

The Hydrochelidon leucopareia is justly entitled to a place in our avifauna; for it has been several times killed in our island, both in its youthful light and in its mature black livery; one in the former state was obtained at Scilly, while the specimen which, through Dr. Heysham's instrumentality, came into the possession of $\mathrm{Mr}$. Yarrell, another obtained in Ireland, and a third kindly sent to me by Mr. Gatcombe, are in the latter dress. The British Islands are not, and never have been, one of the true homes of the bird; those homes lie far south and east of them, for they are the fluviatile marshes and inland waters of the countries bordering the Mediterranean, in Hungary, and in the Crimea. The bird appears in Malta in spring and autumn, but, according to Wright, is not common. The individuals that are then seen are doubtless on their passage to and from Algeria to Southern Europe. It frequents all the great lakes and swamps of North Africa, and is probably common in all parts of that country and thence eastward to the Nile, in Persia, India, and China. The Rev. Mr. Tristram, speaking of the bird as seen by him in North Africa, under the name of Sterna hybrida, says :- “ Hundreds of lovely Terns were hovering about or dipping headlong into the dark still water of Lake Halloula. I shot several, and found most of them to be the Whiskered Tern (Sterna hybrida); but mingled with them were many of the Black and Lesser Terns (S. nigra and S. minuta). Sterna hybrida is easily distinguished by its note, which is less shrill and more rapidly repeated than that of $S$. nigra; but in general appearance it very closely resembles the $S$. arctica, so familiar on our own Northumbrian coasts, with its lake-red bill and feet and its black head. Searching for the nesting-place of the Terns, I was surprised to find the whole colony of Whiskered Terns (S. hybrida) breeding in the nests of Eared Grebes, and that apparently without having at all repaired the nests, which could have been only a few days evacuated by their constructors, as we saw hundreds of young Eared Grebes paddling about and living in the open air with their parents. My series of eggs of $S$. hybrida shows a decided tendency to pale green as the groundcolour, and a type clearly distinguishable from that of any other Tern, though somewhat approaching the character of S. leucoptera, which, however, are much smaller, and only exceptionally of a greenish ground. The markings are nearly as large as in the eggs of the Common Tern. A favourite food with these birds appeared to be a large hairy caterpillar, which covered the neighbouring marshes at this time in thousands. They were also plunging into the lake in quest of the frogs and newts with which it abounds."-Ibis, 1860 , pp. $157,164$.

Lord Lilford informs us, in his paper "On the Birds observed in the Ionian Islands," \&c., published in the same volume of the 'Ibis,' that the "Whiskered Tern (Sterna leucopareia) is common in winter at Butrinto, and breeds in the marshes of Durazzo" (p. 357).

Speaking of the bird under the name of Hydrochelidon indica, Mr. Jerdon says:- "This Tern is 
exceedingly abundant in India, frequenting marshes, tanks, and rivers, usually preying on aquatic food, not unfrequently hunting over fields, beds of reeds, and marshy ground, where it captures grasshoppers, caterpillars, and other insects. In some parts of the country it roosts on thick beds of reeds, congregating in vast numbers for some time after sunset, till nearly dark; indeed it may be seen in scattered flocks flying in an excited and hurried manner over the surface of the water. This little Tern breeds in large churrs on the Ganges, and probably on most other large rivers. Mr. Brooks sent me eggs procured near Mirzapore."

Mr. Swinhoe, writing of the bird under the same appellation, says :-

"This species is not uncommon on the marshy lands of S. W. Formosa. I have not yet noted it in China, though doubtless it must occur there. A fine male brought to me on the 28th of August had the bill deep-brownish lake-red; the legs and toes Indian or madder-red, and black claws. Its stomach contained several large larvæ of a water-beetle (Dytiscus, sp.), and a few small fish."

Temminck informs us that it is found in Borneo; and so it may be; but I have now good reasons for altering the opinion I expressed in my 'Handbook to the Birds of Australia,' that the bird I so frequently met with on the interior waters of that continent was the $H$. leucopareia, an opinion which induced me to suppress my own name of fluviatilis for the older one given by Natterer: since then I have received several examples from the interior of Queensland in their summer dress, which certainly differ from those killed in Hungary at the same period of the year. The Australian bird is smaller than the European, is of a lighter colour, and has a more silvery hue above, while the black of the under surface is not nearly so dark. Judging from the state of plumage of one of the Australian specimens above mentioned, it would seem that these Whiskered Terns undergo a greater seasonal change than I had previously supposed; for it is not the forehead alone that is becoming white, but the dark smoky grey and black portions of the under surface are changing to white.

The Hydrochelidon leucopareia was first described as new to science in the second edition of Temminck's 'Manuel d'Ornithologie,' published in 1820, from specimens discovered by Natterer in the southern part of Hungary. Subsequently other examples were found in the marshes of Capo d'Istria and on the coast of Dalmatia; and in May 1819 M. Jules de la Motte killed three out of a flock of eight, which remained for two or three days on the coast of Picardy, feeding upon the insects frequenting aquatic plants. Degland has since ascertained that it breeds annually in the south of France. The late Mr. Yarrell was the first to give it a place in the British fauna. "At the end of August 1836," says he, "a party of two or three persons went out in a boat to amuse themselves with shooting sea-birds, and this Tern among others was part of the produce of their guns." The next example.was recorded by Thompson in the 20th vol. of the 'Annals and Magazine of Natural History' as having been shot in September 1839 " on the River Liffey, between Ringsend and the Pigeon-House Fort, Dublin, by John Hill, Esq., and as being deposited in the Collection of T. W. Warren, Esq., of Dublin."

From a communication to the 'Zoologist' by Messrs. J. H. Gurney and W. R. Fisher, we learn that " an example of the Whiskered Tern was shot on the 17th of June, 1847, whilst flying over Hickling broad, in Norfolk. It proved to be an adult female, and contained ova in an advanced stage, the largest being apparently almost ready to receive the shell. In the stomach were found the remains of about twenty of the larvæ of the broad-bodied dragonfly."-Zool. 1847, p. 1820.

Mr. Rodd states, in his 'List of British Birds,' that an immature specimen was obtained at Scilly in September 1851 .

On the 11th of May, 1865, Mr. Gatcombe writes:- "I think it will interest you to hear that a specimen of that, to us, exceedingly rare Tern, Sterna leucopareia, has been obtained off the coast of Devon. It is a fine bird in full summer plumage, and was accidentally detected by me in the hands of a young bird-stuffer, who had just finished setting it up, but had not the slightest idea of its name or rarity. He told me that it was picked up on the water by some fishermen and brought in alive, but that it soon died."

In summer the forehead, crown, and nape are deep black; on each side, from the base of the upper mandible below the eye to the ear-coverts, a stripe of white; neck, breast, back, wing-coverts, upper tail-coverts and tail dark grey; first primary leaden grey, except the shaft and the margin of the basal part of the inner web, which are white, the remaining primaries and the secondaries grey, of a lighter hue on the outer than on the inner webs; all with white shafts; chin and throat greyish white; abdomen, flanks, and thighs leaden grey; under wing and tail-coverts white; bill red, darker towards the point; irides brownish black; feet and webs coral-red; nails black.

The Plate represents an adult in summer plumage and a young bird in the first autumn plumage, of the size of life. 


\section{$2 \mathrm{BHL}$ Biodiversity Heritage Library}

Gould, John. 1873. "Whiskered Tern, Hydrochelidon leucopareia [PI. 77]." The birds of Great Britain 5, -. https://doi.org/10.5962/p.324121.

View This Item Online: https://www.biodiversitylibrary.org/item/222497

DOI: https://doi.org/10.5962/p.324121

Permalink: https://www.biodiversitylibrary.org/partpdf/324121

\section{Holding Institution}

Smithsonian Libraries

\section{Sponsored by}

Biodiversity Heritage Library

\section{Copyright \& Reuse}

Copyright Status: Public domain. The BHL considers that this work is no longer under copyright protection.

This document was created from content at the Biodiversity Heritage Library, the world's largest open access digital library for biodiversity literature and archives. Visit BHL at https://www.biodiversitylibrary.org. 